\section{SALVARSAN IN GENERAL PARESIS}

E. 11. TROWBRIDGE, M.1).

Assistant lohyslelan, State llospltal No. 2 ST. JOSEPH, Mo.

barly last year I presented an article' in 'T'us: JoorNAL, giving the genelal negative jesults obtuined in the tratuent of equeral paresis with selvarsan by the subeutaneous method of administration. The results Were so unsutisfactory, in many cases the salvarsan failing to be absorbed, and the method of arhministation being so paintul, that we discontinued its use and have since used the intravenoms method.

Tlie following anses were selecterl with the irlea of treating patients in gool physical health and showing the fevest possible simptoms, mental and physical, of the ravages of this discase. As is known, patients received in a state institution have run the gamblet ol physicians and quacks and are finally taken there, as to a court of last alpeal, the result being that they are generally far enough advanced in the discase to prevent many mistakes being made in cliagnosis.

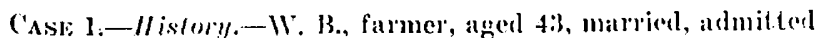
to hospital leels, 4, loll. One comsin insance Previous health good up to two years before admission when symptoms of mental trouble apperared. Cause of trouble given as sunstroke. Patient noisy and incolorent on admittance.

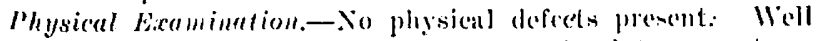
nomished. Alimentary, mespiratory ame circulatory systems normal. Cinit mustendy; slight atrxia and aphasia present. Voice paretice lucoherent and delusional. Patellar and plantar reflexes absent. No ankle-clomus. pupillary rellex reslued. Arayll Robertson pupil absent. Crine negative.

Treatment ard licsults.-On lieb. 6, 1911, the Wassermann reaction was found to be pusitive. following admission putient becane quieter mul reminined in good health, at times. however, becoming slightly disturbed, his mental eomdition chunging lut little. On Miareh 4, 1912, patient was griven $0.6 \mathrm{gm}$. sulvarsan intravenously. positive leaction followed and was slightly disturbed for a fow days. March 20 the Wassermann was found to be still positive and on Marels 20 a serombl lose of $0.6 \mathrm{gm}$. of sulvarsan was givell. l'ositive renction followed with some mental disturbances for a few days. l'ntient soon became quiet and remained nbout the same. A Wassernann made ngain on fune 7 was fomd to be positive. A repetition of the Wasscrmann on Sov. 7 . 19l2, gave a positive finding. At present he is quict and orderly, enting nud sleeping well, in good lealtl and his mental condition remains stationury. Ju this case we get practically no change, except slight disturbanees following the acpministration of salvarsan, the pationt's condition at present being about the kane aly just provious to its usc.

Cass 2.-Mistary.-H. B., married, laborer, nged 25, admitted to honpital sept. 18, 1911. Lamily history negative. Previous health good in to two years previous to admission when symptoms of mental trouble developed. Canse of trouble given as syphilis. patient cigner-smoker since 7 yours of nge. greatly ilcpressed on admittance.

Physical Examination.-No physical defects present. Well Hourished. Alimentary and respiratory systems normal. Heart normal. P'ulse $7 \dot{4}$, irregular and weak. Arteries slightely hardened. (ixit unstendy. No ntaxia present. Aphusia and incoherence present. Delusional. Putellar rellex greatly increased. Plantar nornul. No ankle-celoms. P'upillajy reflex reduced. No Argyll liobertion pupil. Irine negative.

Treatment and Resulls.-Oet. 4, 19]1, the Wassermam reaction was taken and found to be positive. Patient improved somewhat montally and physically following admission, and on Jan. 10, 1912, was given 0.6 gim. salvarsan jntravenously. Hassermanu reaction made feb. 9, 1912, on blood and spinal

1. Trowbitgere, jo. II.: Subentuncous Injectlons of Silvalsan in

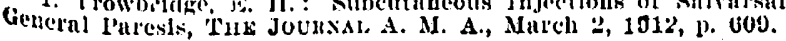

fluid; both fouml to be positive. Salvarsan was given again Marels 7. March 20 the Wassermaun reaction was still positive. Jatient began failing mentally following the second dose of salvarsan. Alaxia appeared and aplusin increased and he beame very irjitable. His general health, however, remained grool. On August $2 \cdot 2$ convulsions appeared and he died on Aug. 25, J!12, from exhaustion. In this ense the patient improved somewhat up to the second administration of salvarsan, when decline set in and he failed rapidly, dying in five months. The nse of salvarsan in this case no dorbt nerely lastened the end.

Cass: 3.-History--J. B. l., farmer, aged 50, married, admitted to hospital Oct. 25, 1911. One cousin insane. Previous health gool up to a sliort tine before admittance when symptoms of mental trouble apjeared. Cuuse of trouble unkuown. Patient greatly disturbed and very delusional on entering lnospital.

Physical Wramination.-No plysical defects except a small goiter present. latient farly woll nomrished. Alimentary and respiratory systems normul. lleart and valves normal. Artedies slightly latdenod. Pulse 120, regular, weak. Gait steady. No ataxia. Aphasia and incoherence present. Patellar and plantar reflexes increased. No ankle-clonus. Pupils uneyual. Pupillary refles reduced. Argyll Robertson pupil absent. Urine nogntive.

Treatment and Rcsults.-On Nov. 2, 1912, the Wassermamn reaction was made and found to be positive. 'lhe patient's condition did not improve and on Dec. 4, ]911, he was given $0.6 \mathrm{gm}$. salvarsan. Following this lie became quieter, enting and sleeping much better, but did not improve at all mentally. On Jan. 4, 1912, the Wassermann reaction was made and found to be slightly positive. Salvaisan was given again on danuary lo. February 9, Wassermann reaction was repeated aud foumd to be negative. No mental improvement followed, lut putient slowly improved physically wntil August, when le began to fail somewhat physically, ataxia appearing and mental symptoms increasing. Novenber 7, Wassermann reaction was found to le positive. November 19, $0.0 \mathrm{gm}$. of alvarsan whs again given. At present he is still declining slowly mentally and pliysically. In this case physical improvement set in following the use of salvarsan, but its good effects seem to have been only temporary and the gencral progressive symptoms reappeared after a few showt months, the disease continuing on its slow course of destruction.

('ASE 4.--History.-W. D. R., a tinner, aged 45, widower. Admitted to hospital Nov. 2, 10]l. Fumily history negative. Previous health good up to one year before admittance when symptoms of mental trouble appeared. Cause of trouble given as alcoholism. Patient greatly disturbed and very delusional on admittunce.

Physical Examination.-No pliysical defects present. Patient in fuirly good physical health. Alimentary and respiratory systems noimal. Heart and valves normal. Arteries somewhat laudened. Pulse $\$ 0$, regular but weak. (iait steady, no utaxia. Aphasia and incoherence present. Jatellar refiex increased. Plantar reflex alsent. No ankle-clomus. Pupils equal but contructed. Argyll Robertson pupil present. Urine negative.

Treatment and Results, - Wassermann reaction made Nov. 25, 1911, was fomd to be positive. Patient improved somewhat physically following admittance, but remained noisy and unchanged mentully. Jan. 20, 1912, he was given $0.0 \mathrm{gm}$. of salvarsan intravenously. He became quieter in a few days but slowed no mental improvement. Wassermann reaction, made ficbruary 20, was still positive and salvarsan was given ugain, Murch ll. Slight menta] jmprovement followed this and loe ute and slept better. Jume 7 the Wassermunn was still positive. He romained in good health and was quiet and well belated until the latter part of September when he becume disturbed, becoming very combative and unruly. November 7 Wastermann reaction found to be still positive. At present he is slowly declining mentally and physically. In this case we seom to have a slight temporary improvement both mentally nud physically followed by the return of the usual symptoms of the disease. 
(Asl: 5.-History.-M. H., " jainter, single, aged 29, admit. tall to hospital Nov. 8, 1911 . Family history negative. P'revious liealli good up to one year before admittance when symptoms of mental tronble appenred and ho became suddenly violent. Cause of trouble given as syphilis. Patient grently disturbed nnd tronbled with many delusions and auditory lanllucina. tions on entering hospital.

1hysical Examination.-No plyesical defects present. Fairly well nourished. Alimentary und respiratory systems normai. Irat and valves normal. Arteries slightly hardened. Pulse mo. regular, weak, Gait steady. Sliglit ataxia present. Aphasia and incoherence present. l'atellar reflex increased. Plantar reflex increased. No ankle-clonus. Pupils contracted. Argyll Rolertson pupil present. Lrino negative.

I'reafment and Results.-W'nssermunn reaction was mado Nov. 25, 1911, and found doubtful. Wassernamu renction whs made on blood and spinal thid, December 12, and both fousd positive. Patient improved somewlat mentully and - physically following admission and ate and slept better. Fob. 20,1912 , he was given $0.6 \mathrm{gm}$. salvarsan intravenously, and Marcl, 20 the Wasserman was found to be still positive. Salvarsan was repeated March 26, 1912. Patient slowly improved following the second dose of salvarsan, and the Wisscamann made April 11 was found to be slightly positive. Jle wis discharged April 27 by request and pussed from observation. At time of discharge patient was in gool physical health, quict, and had hut few delusions, but his mind was enfeebled. In this case there was marked improvement following the use of salvarsan, lint from previous experience, I nuticipate a return of the symptoms and decline of patient with a rendmission to hospital in near future.

CASE 6.-IIistory.-E. W. J., aged 20, an undertaker, married. admitted to hospital Nov. 11, 1911. Family history neg. ative. Previous health good up to abont a year and a half before admision, when he became unbalanced mentally and forged a signature to a small clseck, was sent to the penitentiary for a short time and paroled. On admittance patient very noisy, combative and delusional.

Physical Examination.-No physical defects present. Fairly well nourished. Alimcntary and circulatory systems normal. Gat steady. Slight atuxia present. Aphasia and incoher. cicce present. Patellar reflex increased. Plantar normal. No rnkliceclonus. Pupillary reflex reduced. No Argyll Robertson puljil. L'riue negative.

Treatment and Results.-Wissermajn reaction was made Nov. 25, 1011, and found to be positive. l'atient improved slowly mentally and physically following admission, and Jan. $26,1912,0.6 \mathrm{gm}$. salvarsan was given. Three days after administration of the salvarsan, patient had a convulsive seizure followed by a partial paralysis of the entire right urm and leg which lasted about a week when full use of urm und leg was recovered. Februnry 9 a Wassermann was made (nil both the blood and spinal fluid and found to be positive. linprovement continued, and March 11 patient was again giver $0.6 \mathrm{~mm}$. of salvarsan. Wassermann reaction made in June still positive. Condition continued to improve, and o.t. 2 - 1912 , patient was paroled home in very good physical heralth and much improved mentally, though his mind was cufeebled. In this case, as the Wassermann reaction remains positive. I helieve that sooner or later active symptoms will reappen and that the patient will have to return to the Jospital.

Cass: 7.-History.-W. S., a printer, aged 42, married. Admitted to hospital Dec. 14, 1!11. Family history negutive. Previous health good up to "few months before odmittance. when symptoms of mentul trouble appeared. On entering hospital patient under the influenee of liquor, but quiet. Admit. ted having syphilis of about fiftecn years' duration.

Physical Liamination.-No physical defects present. In grood physical henlth. Alimentury and respiratory systems normal. Heart and valves mormal. Arteries slightly hardened. Pulso 120, regular und werk. Guit steady. So atuxin present. slight npliatio present. No incoherences. Patellar refles incerated. Plantar nermal. No ankle-clonts. Pupily con- tructed and mequnl. Argyll liobertson puzil prescent. Slight trace of sllumin in urine.

Treretment and Results.-Wassermamn reaction made becember 19, positive. Patient remained in good health and in fairly good shape mentally excepting one systematized delusion of vast tracts of land which he owned. Jan. 17, 1912, patient was given $0.6 \mathrm{gm}$. salvarsnn. Condition remaine l unchanged till February 4, when he becume disturbed, an!l slight utaxia appeared with a marked muscular tremor which lasted for forty-eight hours. March 2 he was given seeond ulministration of snlvarsan. March 20 Wnssermann reaction still positive. He failed slowly following this and betame disturbed every fow days and at times combative. Novembe: 7 Wassermann reaction was taken and found positive. Tho jatient's slow decline continued and at present he is very' delusional, mind grently enfeebled, and at times filthy and umtidy. In this case the patient seemed to be getting along fairly well until a few days following the use of salvarsan. when he begnn to decline and the course of the disease seemed to be intensified by the continuation of the treatment."

Cass 8.-History.-J. P. B., man, aged 36, single, no oceupation given, admitted to hospital Nov. 16, 1911. Family history negative. Patient in good health up to abont year before admission, when he began failing mentally. Cause of mental trouble not known.

Physical Examination.--No physical defects present. Fuirly well nomrished. Alimentary and respiratory systems normal. leart and valves normal. Arteries hardeued. Pulse 72, reg. ular and weak. Gait unsteady. Ataxin present. Slight aphasia present. No incoherence. Voice paretic. Patellar reflex absent. l'lantar increased. No ankle-clonus. Pupils dilated and unequal. Argyll Robertson pupil present. Urine negative.

Treatmcnt and liesults.-Wassermann reaction made Nov. 25, 1911, wus positive. Patient slowly failed mentally and phisically following admission, becoming filthy and untidy at times. March 4, 1012 , he was given $0.6 \mathrm{gm}$. of salvarsan. Murch 20, Wassermann reaction negative. Improvement set in physically and mentally and he gained rapidly in weight and mind seemed much improved till the middle of May, when he had a temporary set-back and became disturbed for a few days. Improvenent continued following this, and the Wassermann reaction made November 7 was found to be slightly positive. At present he is much improved over his condition on admittance but is slowly failing, ataxia becoming marked and mind growing weaker. This case shows a decided improvement immediately following the use of salvarsan, but as we see the effects of the salvarsan slowly wearing out, by the return of at slightly positive Wassermanin followed by the decline of the patient, we must admit that the benefits of its use are but tentporary; und a repetition may possibly help or may intellsify the destructive course of this disease.

One has but to glance at these cases, if they may be taken as examples, to sec that salvarsan in the treatment of paresis is as far from giving us any hope for permanent cure as are those drugs relegated to the waste-basket of the past because tried and found wanting. Some slight improvement has followed in a few cases and a crowding of the treatment has, as seen, done naught but intensify the destructive action of this disease and actually hastens the patient's death.

The results obtained by modern methods of diagnosis have accomplished wonders for us in the study of this discase, especially the now universal test of the patient's blood by the Wassermann reaction. Its use brings home to us more and more the saying that civilization and syphilization go hand in hand. More than this. the findings obtained in the examination of patients with this dreadful disease give us practically $100 \mathrm{per}^{\text {r }}$ cent. of positive results, showing beyond a doubt that paresis itself is primurily a disease of syplialitic origin.

1. Jan. di, 1913: The patlent has had ovel thirty convulsions during the past two diys. Dentl is expected at any moment. 
Statistics show that insanty is increasing at a mojed mite. Syphilis las been found to exist in rases not thought of heretolore. Paresis, incurable as it stands to-day, is cutting off more and more men at the heiglit of their aleers, and we stand helplessly by seeing the pationt slowly fail and die in such a depleted condition that worels fail to convey the lomplible nicture except to those who have come in contact with this dreadful Ecourige.

Since Jan. 1, 1911, there have lreen anduitted to my serviee in the hospital eighty-cight cases of general paresis among the male patients. of this number thinty-six lave died, ten have been paroled by request, and those remaining are constantly losing gromol.

At present there are lut two ways of working toward the eladication of this disease. 'The one with which we can accomplish the most is the education of the publice in knowledge of the future evils of syphilis and how they may be perented by immediate treatment. The other rests with those who are devoting their time to scientific l'escirch, and who will sooner or later disenver the intermediate process of toxin which is causing this discase, and grive to the world a curative drug.

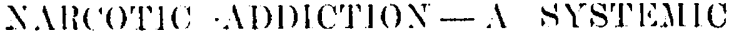
DISEASE CONDITION

ERNGL $\&$ BISHOP, M.1). NEW YOkK

'loo lifte stuly, olservation and cfiont to interpetet plysical manifestations lave been given to those unfoltumates suffering from mareotic aldiction. Ire have neglected their disease in its origin and subseguent progress mul have formed our emeeption of them from fully developed conditions and spectacular end-results. Ve have seen them churing or alter our fluitless eflorts at treatment, heir tortures and poor plysical condition overeoming their resolutions, mutil they plead for and attempt to obtain more of their dlug. We have seen them exhansted, starved, with locked-up elimination. toxic from sel[-made poisons of faulty metabolism, worn with the struggle of encealment and hopeless resistanec, semi-irresponsible beings, at present or soon to be inmates of institutions affording custodial care.

On liternture pictures them as wenk-minded deteriorated wretches, mental and moral derelicts, pandering to morbid semsuality; taling a drug to soothe them into dream states and give them languorous delight; held by us all ju despite and disaust, and regarded as so depraved that their rescue is impossible and they unworthy of its attempt.

$\mathrm{V}_{\mathrm{r}}$ lave ignored or misinterpleted intense plyssical agony and simptomatology, and regarded failure to Hbstain as cvidence of weak will-power or lack of desire to forego morbid pleasure. We lave prayed over our aldicts, cajoled them, exhorted them, imprisoned them, treated them as insane and made them social onteasts; either refused them almission to our lospitals or turned them ont after inclficient treatment with their addiction still fastened to them. They lave realized our failure to appreciate their condition and to offer help for it, Hnd have, after desperate trials of quacks, cliarlatans and exploited "cures," finally acecpted their slavery, and by regulation of their diug and life, muintained unsuspected as nearly nowmal an existence as possible, or, broken and impoverjshed, given up the ;truggle. From these last we have painted our picture. Confined and obscrved hy the institution alienist, or concealed as fimily skeletons in many homes, descriptions of them have given to the whole class of narcotic addicts their prescnt status - cases of mental disease due to drug action or labit deterioration and based on inherent lack of mental and moral stamina.

It was with the above conception of these conditions that I began my work in the Alcoholic and Prison Service of Bellevie Hospital, attracted not by hope of helping "jags" and "dope-fiends," lont by the mass of general clinical material admitted to those wards. When I left the service after sixteen months of day and night observation, with personal oversight and attempt to care for about a thousand patients a month, my early and faulty ronception was replacer by a settled conviction that these cases were primarily medical problems. I realized that the patients were people sick of a definite discase conclition, and that until we recognized, understood and treated this condition, and jemoved the stigma of mental and molal taint from those rases in which it did not exist, we should make little headway toward the solution of our problem.

It is a fuct that the nareotic drugs do afford pleasurable sensations to many of those not yet fully addicter to their nse, and that this effect has been sought by the mentally and morally inferior purely for its enjoyment and in the same spirit that these individuals yield themsolves to other molloil excesses and indulgences. 'This class is, howerer, self-eliminating, and its members rarely present thenselves for treatment.

There is, however, from my observations, obtained in Bellevue Hospital and in private practice, another class, including a large proportion, if not a majority, of narcotic adlicts, in whom there is no inherent mental ol moral inleriority, often men and women of high joleals and worthy accomplishments, whose knowledge of nurcotic achinistration is, in many cases, first gained by withcluawal agonies following cessation of medication, who have never experienced pleasure from the diug, normal mentally and morally, unquestionably victims of a purely physical affliction.

In the literature on narcotic drugs I found very little as to their action or as to the manner of produc. tion of symptomatology in those habituated to their use. 'I'lis experience lias been paralleled by some of my patients, plyysicians of high standing, for many years unknown addicts, and zealous searchers for any information as to their affliction which might offer them hope ol cure. The literature on narcotic addiction is notable for a persistent effort to interpret drug action in an addict by its observed action in normal men and animals, attributing to supposed enjoyment plus direct action of the drug, plus hypothetical mental and moral taint, the clinical picture of chronic llug addiction.

Since realizing the foregoing, I have been endeavoring to search out and explain from study of the individual addict and his corroborated testimony, and from clinical olsservation of his disease, the phenomena and symptomatology peculjar to addiction, and to formulate a theory for their production which would give a rational basis for therapeutic effort. Morphinism is the best cxample of pure adliction, created in most of the patients who seek treatment independently of environment and of personal characteristics. I shall, theretore, in this paper, confine myself to a discussion of morphinism, leaving the application of my conclusions to alcoholism and other narcotic problems for future consideration. 